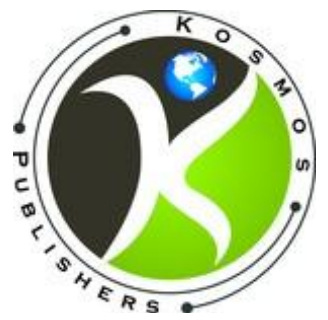

www.kosmospublishers.com contact@kosmospublishers.com DOI: 10.37722/ANAFS.2021303

\title{
The Effectiveness of Nutritional Education Action in Increasing Fruit and Vegetable Consumption by Children and Adolescents in the Municipality Of Viana, ES
}

\author{
Luciene Moreira Silva Campos* \\ Católica de vitória centro, Universitário, Paula regina campos /fcses
}

Received Date: August 17, 2021; Accepted Date: August 25, 2021; Published Date: August 31, 2021;

"Corresponding Author: Luciene Moreira Silva Campos, Católica de vitória centro, Universitário, Paula regina campos / fcses. Email: nutriluciene@ hotmail.com

\begin{abstract}
This paper describes the importance of Food and Nutrition Education activities to promote healthy eating habits developed by children and adolescents from the NGO Gabriel Dillane, located in the city of Viana, Cariacica- ES. During the study period, food and nutrition education activities were carried out, during which combined group and individualized procedures were carried out. The applied activities allowed collective and individualized interventions with stimuli for students to actively participate in the choice of food through playful and interactive activities, which favored the main changes in attitudes and eating practices.
\end{abstract}

In order to verify if the Nutrition Education Activities were effective, individual interviews were carried out with the application of the food frequency questionnaire to verify if they are consuming fresh foods and industrialized foods. The results indicate that the activities stimulated the curiosity of children and adolescents about the practice of healthy eating, positively with good patterns of eating performance, raising awareness of the importance of positive learning of this behavior for proper formation of eating habits, and effective factor for growth, development and maintaining health.

Keywords: DCNT; Eating habits; Fast Food; Healthy eating Food and Nutrition Education; Health Promotion; PAT

\section{Introduction}

Proper nutrition is indisputable at any age. However, the nutritional transition process has negatively contributed to a healthier life, even in childhood. Thus, an option to reverse this condition would be to implement Food and Nutrition Education Activities in the place where children and adolescents live most of their time, thus allowing for the acquisition of fundamental knowledge about food and nutrition.

Missagia et al. (2012) describe the growth and development of healthy children and adolescents will depend largely on access to sociocultural and affective environments that encourage and enable the development of their skills and thus achieving their goals within the potential of each.

In these spaces, it is possible to articulate and expand the knowledge produced by teaching and non-teaching professionals, by students and by the school community, and develop activities that can make everyone aware of the promotion of healthy habits and quality of life (ARNAIZ, 2005).

In other words, we are simply considering that wellinformed people are more likely to actively participate in promoting their well-being (MISSAGIA et al., 2012).

Information about the risks of inadequate nutrition can be the way to develop personal attitudes that promote health. Thus, it is argued that the implementation of a set of educational actions, that is, the development of nutrition education, in any 
educational environment, can be seen as a promoter of health, longevity, life and knowledge (OLIVEIRA; FISBERG, 2003).

Food and nutrition education for children and adolescents requires a multidisciplinary team, including teachers, psychologists, nutritionists and other health professionals. When it comes to the nutrition of a child or adolescent, it should be taken into account that it is a growing organism, with an energy need for vitamins and minerals nutrients, these needs should be valued by developing a diet that is acquiring all the nutrients that are essential for the maintenance and balanced growth using means that attract them to a healthy diet (MANÇO; COSTA, 2004).

Ministry of Health produced the ten steps for healthy eating, for the Promotion of Adequate Eating, with the objective of making the population aware of the importance of promoting health and maintaining adequate weight and the importance of practicing and preventing excess weight (MENDONÇA; ANJOS, 2004).

Thus, nutrition education must work with the natural motivators, which are in the lives of children and adolescents, meeting reality to generate knowledge. In view of the reflections made during the teaching exercise, the importance of giving voice and time to the subjects is recognized, with the objective that their anxieties, concerns, expectations and questions are valued (BOOG, 2008).

In this context, the Nutrition Education action carried out in a playful manner, will to encourage children and adolescents to develop - if a language, of thought, preparing them to be an appropriate citizen capable of facing the obstacles that may arise along the way. According to the literature refers to jokes and games committed in a healthy way are essential works for health physical, emotional and intellectual of healthy children and adolescents (MIRANDA et al., (2008).

In Souza's (2013) view, the school is the space responsible for enabling students to not only move in society, but, above all, to be able to change their social environment. And these conditions that will be given so that the environment, in which the subjects live, is modified, become possible through educational actions developed by the family, community and school.

The school provides the opportunity to build tools for the social environment to be modified and rebuilt. This possibility that is given by the school, promotes the link offering interdisciplinary projects on transversal themes, incorporation of transversality in the subjects, as well as a work in which transversality is inserted as a hidden curriculum (ARAÚJO, 2003).

Thus, this study aims to evaluate the application of Nutrition Education tools for children and adolescents who attend the Non-Governmental Organization in the Municipality of
Viana Cariacica -Es to promote health and quality of life in the short and long term.

Considering that the increasing prevalence of overweight and obesity in children and adolescents in recent years and has been considered a worldwide epidemic, it is important to develop attitudes to change these epidemiological data. Therefore, it is important to investigate the change in eating behavior in children and adolescents with bad eating habits. These are actions of great importance for them, thus verifying whether nutritional education tools are effective in these changes. Therefore, it is important to approach this subject in order to study its probable causes, complications, and treatment.

Therefore, an option to reverse this condition would be implementing Food and Nutrition Education Activities in the place where children and adolescents live, thus allowing for the acquisition of fundamental knowledge about food and nutrition.

Food and Nutrition Education (EAN) is a strategy recommended by public policies in food and nutrition. As a fundamental tool for promoting eating habits healthy. The issue of promoting healthy eating habits came to be part of official national programs, such as the National Food Policy and Nutrition (PNAN), implemented in the late 1990s, in which the promotion of actions in food and nutrition, including the aspect of access global to food (MIRANDA et al, 2012). It is also noteworthy that, in the period between 1990 and 2010, people came to be treated as holders of rights, and were then called to expand your power of choice and decision. In this context, the National Program of School Feeding (PNAE), established in Brazil since 1955 and reformulated over the decades, it exhibits, among its purposes, the conception and development of healthy eating habits of students through actions of EAN (POLLA; SCHERER, 2011).

Thus, with this probability, the increase of an educational work with this approach may expand the knowledge of children, adolescents and their family members around care with food and nutrition, allowing and benefiting healthier food alternatives (FROTA; BARROSO, 2005).

Nutrition assures the child a good development, in good conditions appropriate, such as good health and promotion of food in quantity and quality. From the beginning of preschool to adolescence, they increase between 5 and $7 \mathrm{~cm}$ and gain about 2 to $3 \mathrm{~kg}$ annually. Eating habits are constituted in childhood and when inappropriate, they may be collaborating in a negative for the health of the adults of tomorrow. Likewise, there needs to be a care with limited diets so as not to harm growth and development childish. Contraception for certain adult degenerative diseases begins in childhood (FARIAS; OSÓRIO, 2005).

The design and development of eating habits begins with the genetic aspect and deals with the environment the breastfeeding received in the first years of life; a and how 
complementary foods were placed in the first years of life and their experience had good and negative results regarding food in the course of childhood; family habits; socioeconomic status, among others. Therefore, nutritional recommendations and eating habits need to tend for a singular purpose of the emotional, social and physical well-being of children and adolescents (CARVALHO; OLIVEIRA; SANTOS, 2010).

According to the study by Kock and Leite (2014), it is believed that nutrition education is a primary instrument for the promotion of healthy eating habits, in a way the author reports the importance that nutrition education can bring as well as individual health.

The theme shows that Food and Nutrition Education encompasses changes and improves eating habits in the medium and long term, and is related to representations about food, knowledge, attitudes and values. The education food and nutrition plays an essential role in the promotion of healthy eating habits from childhood.

The purpose of nutrition education is to help subjects to establish methods and eating habits that are adequate to the needs of each one. Following this idea, it is up to the educator to create the subject's desire to change their way of eating. Health has to cover resulting from the quality of life, in this way, health is discussed and created so that everyone has access to information related to health and living conditions, so that the entire population lives in adequate conditions (SOUZA; RONDÓ, 2000).

In the view of Manço and Costa (2004), nutritional education aims to teach individuals to make healthy food choices. According to the authors, educational actions in nutrition will guide the individual to build a better view of healthy eating habits.

Manço and Costa, (2004) consider nutritional status as an important factor for learning, according to the author, nutritional education must be provided in time, when changes in behavior and eating practices are still possible. Many authors advocate that changes in the eating habits of schoolage children are more easily influenced in the first years of school.

It is understood that nutrition education should not be taught only in theory. The acquisition of a healthy diet is an educational process and is acquired through practice. Nutrition education is one of the emerging needs in our society. Damage related to health and quality of life would be the price to be paid side by side and awareness of good nutrition permeates the development of public policies in our society (BOOG, 2008).

\section{Methodology}

The current work is a descriptive, qualitative, longitudinal and observational. The study took place at (NGO), located in the municipality of Viana, Holy Spirit. The defined population was 63 children and adolescents aged six to twelve years of both sexes. The sample inclusion criteria were children and adolescents aged female and male over six years old, who attend the NGO and live in the municipality of Viana, Cariacica-Es. Those who had the parental authorization signed in the Informed Consent Form and the Informed Consent Term and participated in the interview, filling out the food frequency questionnaire.

To obtain data, a food frequency questionnaire was used adapted and validated from the CIASC through individual interviews with children and teenagers, to investigate the consumption of fresh foods, fruits, vegetables and industrialized foods chewing gum, candy in general how many times the population studied consumed these foods daily, weekly and monthly. Through the questionnaire it was possible to obtain information regarding the age of the participants, (children and adolescents) sex and education.

Nutrition education activities were applied to children and teenagers aged six to twelve years in the NGO located in the city of Viana, some of the activities were developed in the classroom, the third and The last nutritional education tool was the implementation of the vertical organic garden, which was prepared in the external area of the NGO and the presentation of food groups from the food pyramid adapted to the new food guide.

The analysis performed in this work consists of exploring the data used in the techniques, Descriptive Statistics (Frequency Distribution and Graphical Representation and Inferential (Chi-square nonparametric test). And qualitative analysis of educational actions carried out at the site. Were used the following programs: Microsoft Excel 2010 and SPSS 23.0 for Windows.

\section{Results and Discussion}

This section presents the results found during this research, starting with the profile of the children and adolescents who participated in the study. Of the 63 children and adolescents who collaborated with the research, 45 were school and 18 were teenagers. Aged from 7 to 12 years old as indicated by the table 1.

\begin{tabular}{|c|c|c|}
\hline Age (Years) & Number of patients & \% \\
\hline 7 & 10 & 15,9 \\
\hline 8 & 19 & 30.2 \\
\hline 9 & 7 & 11.1 \\
\hline 10 & 9 & 14.3 \\
\hline 11 & 13 & 20.6 \\
\hline 12 & 5 & 7.9 \\
\hline Total & $\mathbf{6 3}$ & $\mathbf{1 0 0 . 0}$ \\
\hline
\end{tabular}

Table 1: Distribution of frequencies according to Age of patients 
There is a balanced distribution between males and females, as shown in graph 1 . However, there was a greater participation of females $(52.4 \%)$ compared to males $(47.6 \%)$. This can be explained due to the greater number of women have participated in the survey.

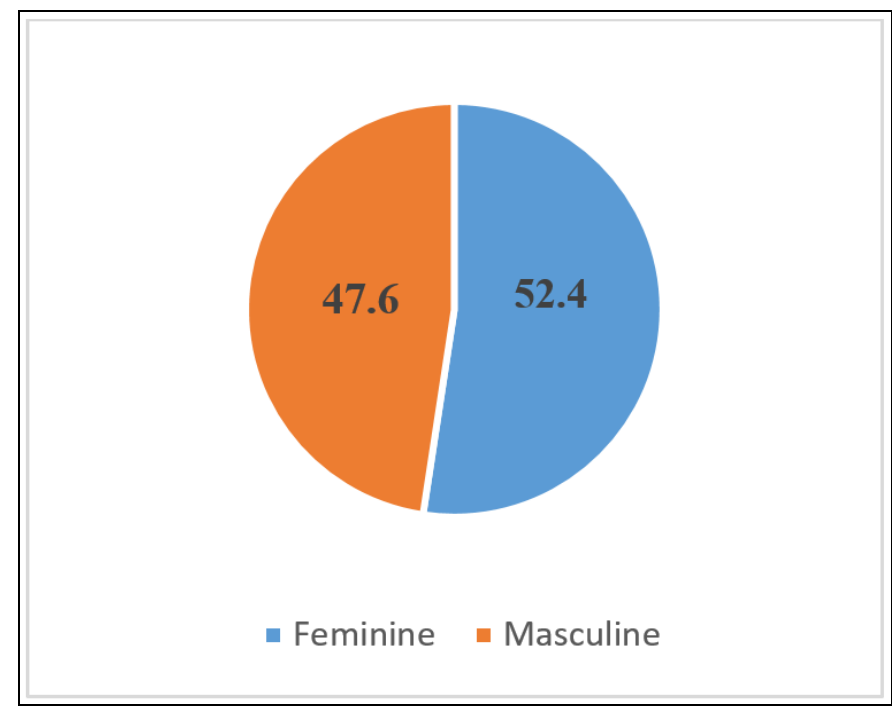

\section{Graph 1: Distribution of frequencies according to Gender}

Considering their age group, it appears that they are in accordance with their education, ranging from 2 nd year for 6 year-olds and 4th for 11-year-olds.

\begin{tabular}{|c|c|c|}
\hline Education (Years) & Number of patients & $\boldsymbol{\%}$ \\
\hline 1 & 4 & 6.3 \\
\hline 2 & 16 & 25.4 \\
\hline 3 & 7 & 11.1 \\
\hline 4 & 19 & 30.2 \\
\hline 5 & 17 & 27.0 \\
\hline Total & $\mathbf{6 3}$ & $\mathbf{1 0 0 . 0}$ \\
\hline
\end{tabular}

Table 2: Frequency distribution according to Patients' Education

After the demographic description, the questionnaire applied contained questions regarding the eating habits of the studied population. The purpose of these questions was routine identification after nutritional intervention.

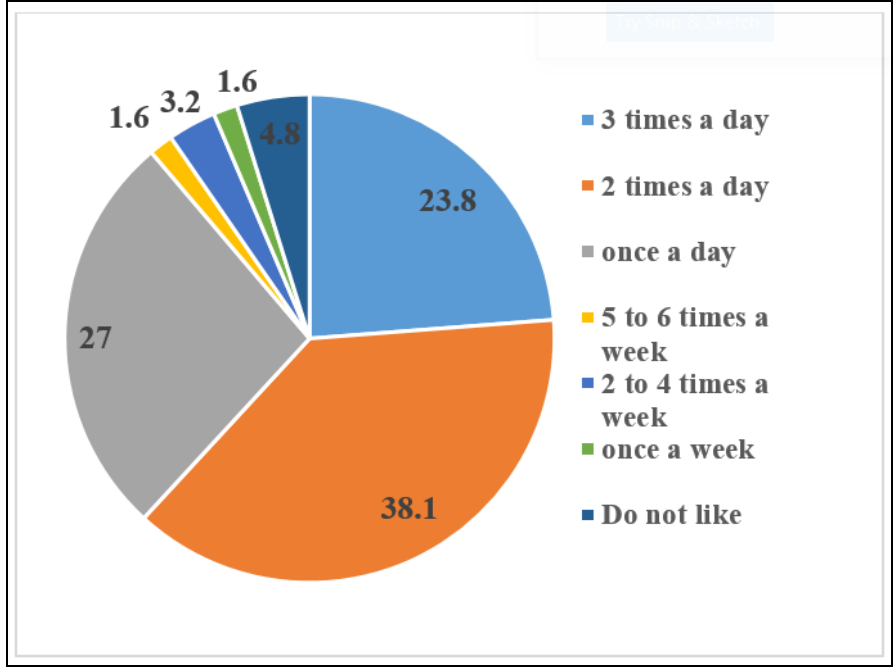

Graph 2: Daily fruit consumption

The fruits most mentioned by the children were apple, silver banana, watermelon guava and mango. The consumption of fruits, as well as vegetables, are premises of healthy eating habits, and it is essential that it be influenced from the family environment to school. It is interesting to note that fruits such as bananas, guava and mangoes are grown by families in their backyards, making them more affordable to children and even constituting their playful universe. With regard to the consumption of fruits by children, it was verified in this study a result balanced in which a greater part $38.1 \%$ of children said they consume fruit twice a day being $27.08 \%$ once a day. Costa, Vasconcelos and Corso (2012) elucidate that epidemiological studies have suggested the importance of consumption of fruits and vegetables in health promotion, being able to prevent diseases non-communicable chronicles.

Also in analysis of the eating habits of schoolchildren, Costa, Vasconcelos and Corso (2012) found in their results that the intake of fruits and vegetables five or more times a day was considered adequate consumption. To test the association between adequate consumption of fruits and vegetables and the variables independent, multivariate Poisson regression was used, considering the level 5\% significance ( $\mathrm{p}$ $\leq 0.05$ ). Adequate consumption was present in $2.7 \%$ of schoolchildren, while $26.6 \%$ did not consume fruits and vegetables even once a day. 


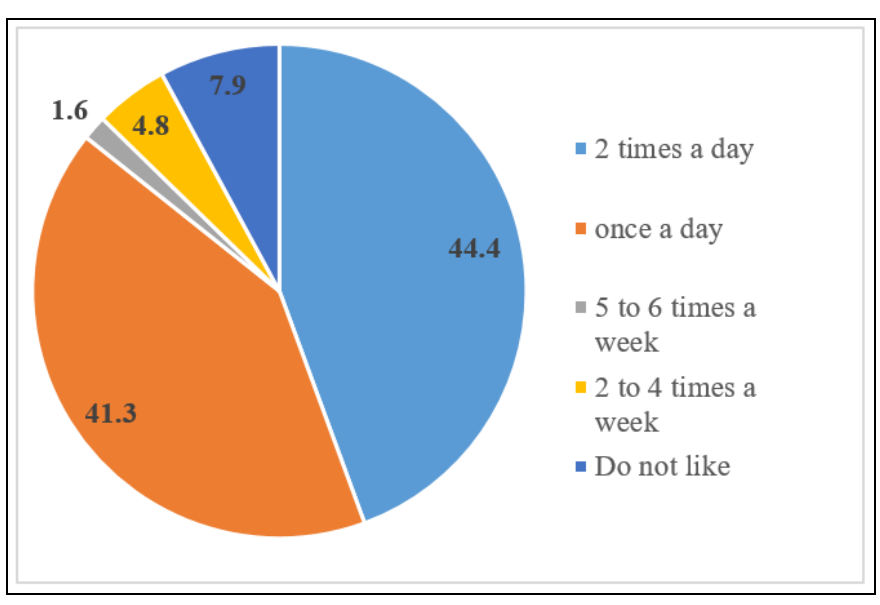

Graph 3: Daily consumption of vegetables

Most children indicated that they consume vegetables daily. This result may be motivated by the fact that most students perform at least 1 meal at the NGO. It is important to mention that these results in relation to consumption of fruits and vegetables is already directly related to the construction of the vegetable garden by the students, a situation in which the benefits of vegetables for the food, collective recipes were built and food produced with the harvest of the vegetable garden. In this way, the influence of the NGO in feeding this population becomes clear.

In the same sense, Muniz et al. (2013) carried out a crosssectional study. School-based that assessed the prevalence and factors associated with daily consumption of vegetables and vegetables (FLV) among adolescents from public schools in Caruaru (PE). In their results, the authors found that the daily consumption of fruit was $63 \%$ higher among residents of the urban area. Daily consumption of fresh fruits/vegetables was 2.4 times higher among adolescents who consume rice and beans daily.

Another study that analyzed the development of the garden as a strategy for educational activities among children and young people the authors found that after the garden children and young people were more willing to try vegetables, more preference for their consumption, greater ability to identify them, as well as an increased consumption of fruits and vegetables and varieties consumed (Morgan et al., 2010).

The results show that applying the school garden as an EAN strategydirects children and teenagers to take better care of plants, also presented itself as a form of participatory education for employees and collaborators involved in order to acquire knowledge about food and creating bonds between children and adolescents. Proceeding with the analysis of eating habits of children, it was found that food consumption is high industrialized among them, as can be seen in Table a below.

\begin{tabular}{|c|c|c|}
\hline Gum and candy in general & Number of patients & \% \\
\hline 2 times a day & 1 & 1.6 \\
\hline once a day & 20 & 31.7 \\
\hline 2 times a week & 2 & 3.2 \\
\hline once a week & 24 & 39.7 \\
\hline once a month & 14 & 22.2 \\
\hline Does not consume & 1 & 1.6 \\
\hline Total & $\mathbf{6 3}$ & $\mathbf{1 0 0 . 0}$ \\
\hline
\end{tabular}

Table 3: Frequency distribution according to industrialized foods

There is a high consumption of processed foods by children. Like $31.7 \%$ chew gum and candy once a day since most consumes at least $39.7 \%$ once a week. It is still necessary to call the attention of children for their eating habits, starting from the environment family, considering that there is no point in intervening in the environment in which the children are part of the time, if the family does not act with healthy habits, considering that they are the two environments with the greatest influence on the development of children, especially minors. It is noteworthy that foods like chewing gum sweets in general presented are the most harmful to health, thus promoting diabetes and obesity among children and adolescents Domingues, Miranda and Santana (2014) verified the eating habits between children with regard to the consumption of processed foods, demonstrating the high consumption of cakes, filled cookies and sweets. In addition, it has been verified the low consumption in the weekly period of cereals and legumes, food intake this one that presented vulnerability in the study population, because they are food basis of Brazilian food. Corroborating the results already described by OLIVEIRA, (2016) that analyzed the consumption of processed foods by category, the results show a high consumption of sweets $(59.5 \%)$, soft drinks and box juices $(42.9 \%)$ and stuffed cookies $(40.5 \%)$ by the adolescents. In this context, there is a need for food education in schools, with interventions that attract children to healthy eating habits, considering that proper nutrition is able to prevent diseases and promote health of individuals. 


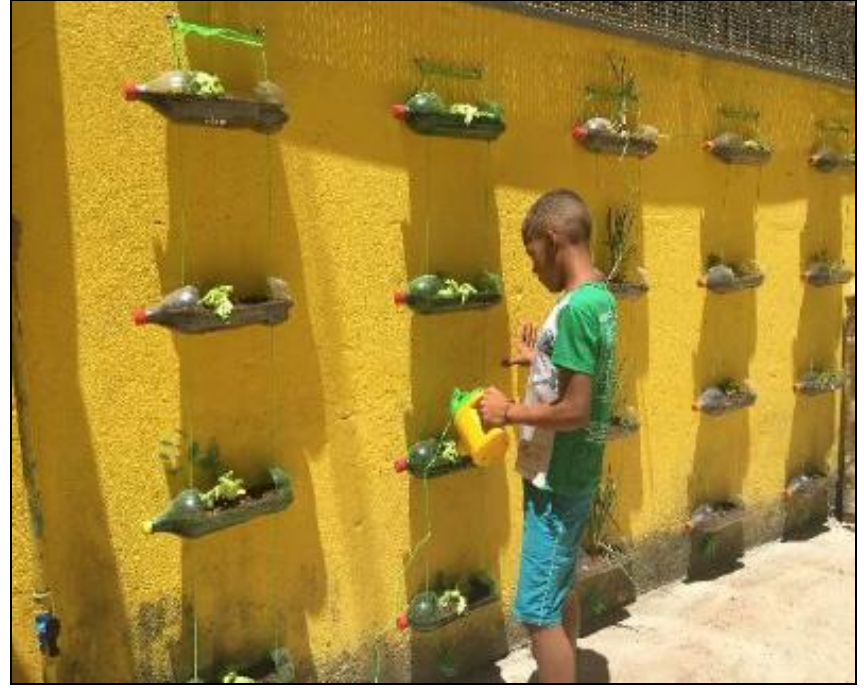

Figure 1: Intervention in the eating habits of children and adolescents

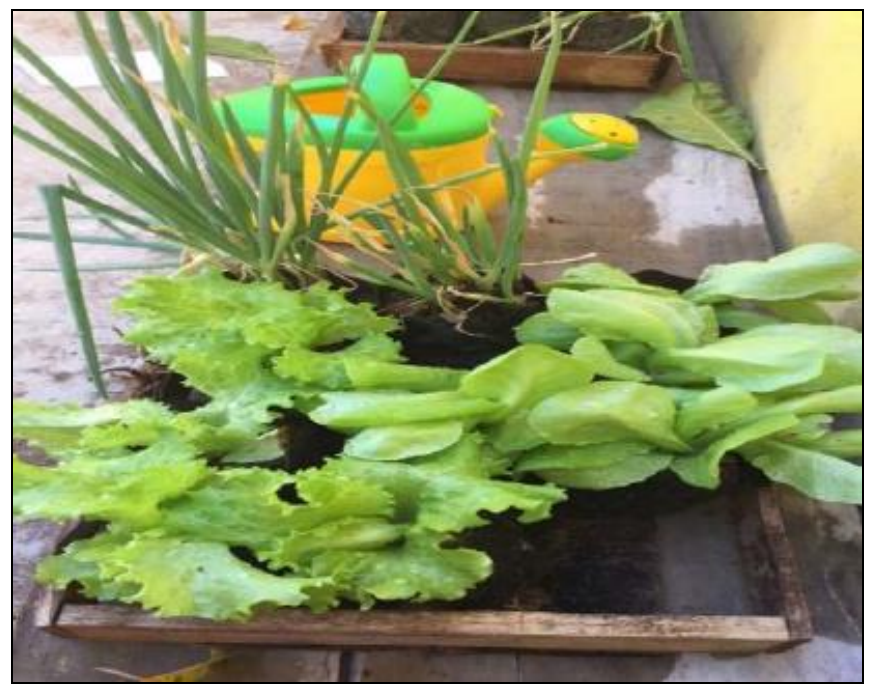

Understanding the socioeconomic conditions of the municipality of Viana and also from Brazil and knowing that the pre-school, school and adolescent phases are periods decisive in the formation of eating habits, it is important to encourage consumption healthy and varied diet from childhood.

According to the characteristics of this population, educational actions nutrition were carried out through group dynamics based on the Guide Food for the Brazilian Population, and all participants received general nutritional guidelines. Such nutritional guidelines were applied through of group dynamics. Miniatures of fruits, vegetables, vegetables and industrialized food in the form of "Bingo" play, worked on identification and importance of each food. Arables from the implementation of the vegetable garden, it was possible to interact with them to know the benefits of spring onions, cilantro, parsley, flat and crisp lettuce as they are part of the most Brazilian menus and are offered daily in the food of the NGOs.
Regarding the role of the vegetable garden as a strategy for EAN, there was a direct relationship with the role of the NGO in the cultivation of knowledge, with activities that were out of line informative and enabled educational practices that, in addition to associating theory and practice, allowed to work on sensitive aspects of knowledge, contributing to the formation of bonds with the food produced in the place. It was evident how much was important and effective to adopt the implementation of the vegetable garden as an education strategy nutritional.

\section{Final Considerations}

The applied activities allowed for collective and individualized interventions where each child and teenager was stimulated with active, playful and interactive, which favored the main changes in attitudes and practices food from them. The present study obtained satisfactory results as it stimulated curiosity of children and adolescents on the practice of healthy eating, since that they reflected positively at home with good examples of behavior food becoming multipliers and aware of the importance of positive practice of this behavior for the formation of good eating habits in the family as an essential factor for the growth, development and maintenance of the health. Given this, the importance of Education activities becomes evident. Food and Nutrition developed in any environment, where children and Adolescent lives part time of the day, so it is of paramount importance that family participation in these Food and Nutrition Education activities mainly because these children and teenagers will be the adults of tomorrow.

In this sense, it is believed that there is still a long way to go in the sense of relating the eating practices taught at school, to the family routine of children and adolescents. However, the survey showed advances in making children aware of the need to build healthy eating habits.

\section{References}

1. CARVALHO SP (2005) As delicadas relações entre construção de hábitos e aprendizagem. Revista Avisa Lá.

2. CAVALCANTI NF, RIBEIRO H (2003) Condições Socioeconômicas, Programas de Complementação Alimentar e Mortalidade Infantil no Estado de São Paulo (1950 a 2000). Revista Saúde e Sociedade, São Paulo, 12:31-42.

3. DAMIANI D (2000) Obesidade na infância e adolescência: um extraordinário desafio! Arquivo Brasileiro de Endocrinologia \& Metabologia, São Paulo, 44:363-365.

4. DIAS P de S, BRITO JAS, COSTA AP (2016) Revista Eletrônica de Administração e Turismo, 8:927-944.

5. ESCODA MSQ (2002) Para a crítica da transição nutricional. Ciência \& Saúde Coletiva, Rio Grande do Norte, 7:219-226.

6. ENO Élen Gomes, LUNA Renata Raimundo, LIMA Renato Abreu (2016) Horta na escola: incentivo ao 
cultivo e a interação com o meio ambiente. Electronic Journal of Management, Education and Environmental Technology (REGET), 20:248-253.

7. FERREIRA HS, FLORÊNCIO TMTM, FRAGOSO MAC, MELO FP, SILVA TG (2005) Hipertensão, obesidade abdominal e baixa estatura: aspectos da transição nutricional em uma população favela. Revista de Nutrição, Campinas.

8. FERREIRA VA, MAGALHÃES R (2007) Nutrição e promoção da saúde: perspectivas atuais. Cad Saude Publica, 23:674-1681.

9. FONSECA VM, SICHIERI R, VEIGA GV (1998) Fatores associados à obesidade em adolescentes. Revista de Saúde Pública, Rio de Janeiro, 32:541-549.

10. FRANCO AC, BOOG MCF (2007) Relação teoria-prática no ensino de educação nutricional. Rev. Nutr, 20:643655.

11. FREIRE P (1997) Pedagogia da autonomia. Saberes necessários à prática educativa. São Paulo, Rio de Janeiro: Paz e Terra.

12. MELLO ED, de et al. (2004) Obesidade infantil: como podemos ser eficazes? Jornal de Pediatria, Rio de Janeiro, 80:173-182.

13. MENDONCA CP, ANJOS LA dos (2004) Aspectos das práticas alimentares e da atividade física como determinantes do crescimento do sobrepeso/obesidade no Brasil. Caderno de Saúde Pública, Rio de Janeiro, 20:698709.

14. MISSAGIA SVA (2012) influência dos valores alimentares e das atitudes no consumo de alimentos saudáveis. Dissertação de mestrado, Universidade Federal de Lavras, Lavras, MG, Brasil. 11-103.

15. MONDINI L, MONTEIRO CA (1998) Relevância epidemiológica da desnutrição e da obesidade em distintas classes sociais: métodos de estudo e aplicação à população brasileira. Revista Brasileira de Epidemiologia, São Paulo, 1:28-39.

16. MONTEIRO CAA (2003) dimensão da pobreza, da desnutrição e da fome no Brasil. Estudos Avançados, São Paulo, 17:7-20.

17. MONTEIRO CA, FREITAS ICM, BARATHO RM (1989) Saúde, nutrição e classes sociais: nexo mpírico evidenciado em um grande centro urbano, Brasil. Revista de Saúde Pública, São Paulo, 23:422-428.

18. MORGADO FS (2006) A horta escolar na educação ambiental e alimentar: experiência do Projeto Horta Viva nas escolas municipais de Florianópolis. 45p. Centro de Ciências Agrárias. Universidade Federal de Santa Catarina, Florianópolis. 18.
19. MORGAN PJ, et al. (2010) The impact of nutrition education with and without a school garden on knowledge, vegetable intake and preferences and quality of school lifamong primary-school students. Public health nutrition, 13:1931-1940.

20. NOGUEIRA WCL (2005) Horta na escola: uma alternativa de melhoria na alimentação e qualidade de vida. In: ENCONTRO DE EXTENSÃO DA UFMG, 8, 2005, Belo Horizonte. Anais... Belo Horizonte: UFMG, $48 \mathrm{p}$.

21. OLIVEIRA CLd, FISBERG M (2003) Obesidade na infância e adolescência: Uma verdadeira Epidemia. Arquivos Brasileiro de Endocrinologia \& Metabologia, São Paulo, 47.

22. OLIVEIRA T (2016) Ferreira Dantas de Consumo de alimentos industrializados por crianças e adolescentes.

23. PEREIRA PJ de A, LOPES L da SC (2012) Obesidade infantil: estudo em crianças num ATL. Millenium, 42:105-125.

24. PERRENOUD P (2000) Dez novas competências para ensinar. Porto Alegre: Artes Médicas.

25. PINHEIRO ARO, FREITAS SFT, CORSO ACT (2004) Uma abordagem epidemiológica da obesidade. Revista de Nutrição, Campinas, 17:523-533.

26. PIPITONI MAP, et al. (2004) A educação nutricional nos livros didáticos de ciências utilizados no ensino fundamental. Piracicaba: ESALQ/USP.

27. SABIA RV, et al. (2004) Efeito da atividade física associada à orientação alimentar em adolescentes obesos: Comparação entre o exercício aeróbico e anaeróbico. Revista Brasileira de Medicina do Esporte, 10:349-355.

28. SANTOS LASO (2012) fazer educação alimentar e nutricional: algumas contribuições para reflexão. Ciência \& Saúde Coletiva, 17:453-462.

29. SANTOS AM, GROSSI PK (2007) Infância comprada: hábitos de consumo na sociedade contemporânea. Revista Virtual Textos \& Contextos. 6:443-454.

30. SILVA JÚNIOR SI (2003) Economia e nutrição. In: OLIVEIRA, J. E. D.; MARCHINI, J. S. (Org.). Ciências Nutricionais. São Paulo: Sarvier, 305-322.

31. SOUZA MC, RONDÓ PH de C (2006) Alimentação na infância. In: TIRAPEGUI, J. Nutrição: Fundamentos e Aspectos Atuais. São Paulo: Atheneu. 342.

32. VASCONCELOS AM Nogales, GOMES Marília Miranda Forte (2012) Transição demográfica: a experiência brasileira. Epidemiologia e Serviços de Saúde, 21:539548 .

Citation: Silva Campos LM (2021) The Effectiveness of Nutritional Education Action in Increasing Fruit and Vegetable Consumption by Children and Adolescents in the Municipality Of Viana, ES. Adv in Nutri and Food Sci: ANAFS-218. 